\title{
Planning of rural areas in the vicinity of the metropolitan areas after the new jurisdiction, 'complete city law': a case from Izmir
}

\author{
F. Akpınar ${ }^{1}$ \& G. Başaran ${ }^{2}$ \\ ${ }^{I}$ City and Regional Planning, Faculty of Architecture \\ Izmir Institute of Technology, Turkey \\ ${ }^{2}$ İzmir Greater Area Municipality, Turkey
}

\begin{abstract}
At the turn of the 1980s, Turkey's economic policy went through a radical transformation by adopting new liberal economy based on exports versus the import substitution policy. During the 1980s, liberalisation and privatisation policies led to the withdrawal of the public subvention mechanism to the agricultural sector that caused rapid immigration to the urban areas and abandonment of the agricultural land. No doubt about it, rural areas in the vicinity of the metropolitan cities, are affected the most adversely as the consequence of the attempts, and encouraged the expansion and suburbanization. On the other hand the new jurisdiction on rural areas, the Law of 6360 (2012) has been the turning point in the Municipal Administrative Structure in Turkey. The law has extended the city boundaries along with the provincial areas including villages and mid-sized provincial districts found in the metropolitan areas. The law abolished all the villages' rural status and converted them to the ordinary neighborhoods of the central metropolitan city. Within these circumstances, the objective of the study is to discuss the possible effects of the new jurisdiction on the rural areas in the planning process.

Keywords: urban-rural interaction, rural index, spatial planning of rural areas.
\end{abstract}

\section{Introduction}

The urbanization process, spreading into the rural areas, caused transformation of the rural settlements specifically within their physical, social and economic structure. The investment projects also directly influenced the transformation. The 
biggest fall-out is the migration from these rural areas to the urban areas. As the rural population shrinks, the economic contribution of agriculture to the Nation's economy declines, while the urban areas suffer the effects of the over-population. This shows the double sided-impact of the migration process. When we look at the history of rural structure of Turkey, during the announcement of the Republic, 77 per cent of the population lived in rural areas, mainly being self-sufficient, somewhat isolated, maintaining century old traditions and life style. With the national industrialization efforts, development projects put in place after the announcement of the Republic, the transformation of the rural areas gained momentum, reaching its peak after World War II, during the 1950s with the injection of new technology and tools, especially, bringing tractors and high tech agricultural machinery, thus shifting the villagers' focus to market based production. There has been no turning back from this transformation, no bringing back the self-sufficient village populace [1]. However, despite all these radical transformation, during the $1950 \mathrm{~s}, 76$ per cent of the population lived in rural areas, whereas 24 per cent lived in urban areas. The picture was reversed after the 2000 census, showing only 30 per cent living in rural areas, and 70 per cent living in cities. Especially, during the EU membership talks, with mainly Government backing away from subsidies and agricultural support, the rural section lost close to one million jobs every year. This caused enormous loss in the rural based economy, and agriculture. Turkey is a country that is fast breaking off its relation with the agrarian society. The ratio of urban to rural areas for the biggest three metropolitan areas (İstanbul, Ankara and İzmir) reached 100 per cent and after the Law of 6360, "The Law of Establishment of 13 Greater Municipality and 26 Districts" (known as complete city law in public), enacted in March 2013 accompanied with the removal of the "Special Provincial Administration (SPA)" (Il Özel İdaresi). With the enactment of the law, the number of the Greater City Municipalities has reached 30 in numbers and 75 per cent of the total population of the country now lives under the jurisdiction of the urban administration. For the Greater area municipalities all the rural areas after the Law 6360 are now considered urban.

The massive flow of the rural population to the urban areas as a result of the high rate of urbanization was not accompanied with the same pace of industrial developments. This led to the informality both in the living environment as the illegal squatter settlement gecekondu (landed overnight in literal translation) [2] and emergent informal sector for those who find difficulty to absorb labour market of the formal jobs. Inhabitants of squatter settlements have become the focus of politicians' efforts to draw votes to themselves thus they have not taken legal steps to solve the problems of unemployment or providing decent living and housing. This forced masses to allocate the public land on the outskirts of the cities. The squatters' need for urban services created opportunity for the political manipulation, and potentials for the electoral patronage [3]. The exchange mechanism of urban rent has functioned on the consent of both, the state and the society. On the other hand, in big Metropolitan cities expansion and suburbanization towards the newly developed areas were accompanied with the displacement of the local low income squatter residents and rural areas. The 
flowing of monetary funds to the urban areas and activities by the big real estate corporations, further promoted spatial inequality. Liberalization generated an intense commodification of informal land and housing markets [4]. Large land areas where squatters live became attractive and offered lucrative potential for constructing large physical complexes as business districts, hyper-towers, marinas, luxury hotels, gentrified neighborhoods and new consumption places by multi-national companies. Under these circumstances low-income segment's land speculation would be unlikely as before and caused difficulty for the new comers from rural areas to integrate into urban life both residentially and economically [5]. These changes brought in substantial variations of pull and push factor of urban versus rural and rural-urban gradient.

\section{Recent changes in the territorial jurisdiction}

The organization and structuring of spatial administrative regulation goes back to the late 19th century, corresponding to the beginning of the Ottoman modernization. Istanbul Şehremaneti which was founded in 1855, and was the first municipal organization of the Ottoman Empire [6]. In the 2000s, Turkey's public administration system entered into a restructuring process with the winds of globalization, basing the new concept of management on the notion of "metropolitan governance" [7]. In the restructuring process certain changes were also introduced in the metropolitan area management and metropolitan administration. Adopted in 2003 but not put into effect, the Law of Public Administration is leading the changes in the administration of the locales. A series of laws including Law No. 5393 Municipality Law, Law No. 5302 Special Provincial Administration (2005), and Law No. 5446 Regional Development Unit, were enacted in sequence. All the laws bear the imprint of the "metropolitan governance". The Law of 6360, complete city law, has been the turning point both in the Municipal Administrative Structure in Turkey and the administration of the rural areas at the vicinity of the metropolitan cities of the country. The law has extended the city boundaries along with the provincial areas including villages and mid-size provincial districts found in the metropolitan areas. This enlargement has been accompanied with the centralization of the jurisdiction under the central city administration. The law abolished all the villages' rural status and converted them to the ordinary neighborhood of the central metropolitan city. The law, at the same time, abolished all the jurisdiction of the SPA, which was previously responsible of the management of the rural areas. The greater area municipality boundary was extended and overlapped with the province limits (Figure 1). With the enactment of this new jurisdiction, the role and responsibilities of urban services along with the financial regulation has changed completely. The planning responsibilities, political representation, and public participation were restructured in accordance with the enactment of the law. Before the law, the responsible public body for the administration of the rural areas was the SPA in accord to the Law No. 5302 enacted in 2005. The jurisdiction according to the law, was composed of the areas which was not under the jurisdiction of the Greater Municipality Area. The SPA was the responsible body of vast rural areas composed of many villages, provinces 
at the vicinity of the Greater Metropolitan Areas. The preparation of the Master Plans, public works, conservation of land, prevention of the erosion, culture, art, tourism, social works, poverty aids, micro-credit to the poor, and various services, were amongst the responsibilities of the Province Administration. The autonomous administrative and financial public body was created to meet the various collective services of the province's population and its decision board was composed of the members selected by the local voters. The province governor (vali) who attained by the existing government was the coordinator of the approval of the Master Plan with the selected "Province General Council" (Il Genel Meclisi).

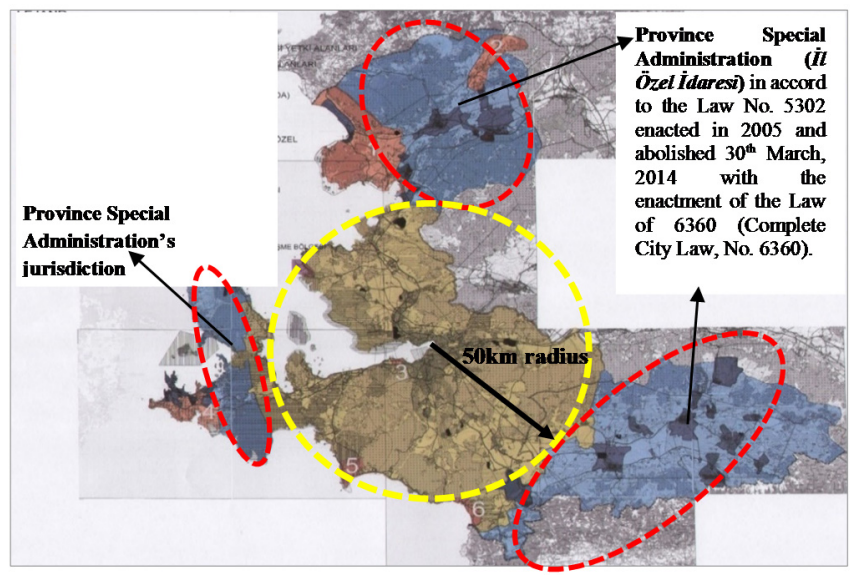

Figure 1: Administrative boundaries and different jurisdictions in Izmir metropolitan area.

\section{The nation's Greater Area Municipality model}

According to [8] the nation's administrative structure is constructed on "administrative division" and "administrative hierarchy". The governorship valilik, is the central government's administration in the city level whereas kaymakam, is the representative of the national governments administration on the town level [6]. According to the Constitution of the Republic of Turkey, there are three kinds of local government: provincial ( $i l$ ), municipal (belediye), and village $(k \ddot{o y})$. By the Constitution, decree 127, "local governments are the public bodies established to meet the local collective needs of the people, which have decision boards selected by the local people". Local governments have administrative and financial autonomy and are formed according to the principle of subsidiarity. Until 1984, metropolitan cities in Turkey were not considered different than other cities. In accordance with the Constitution of 1982, the constitutional decree (no. 127) has brought the right to form special (metropolitan) administrative units for the "big settlement centers". This competency has led to legislation of Law No. 3030 (1984) to construct a dual, hierarchical local administration system, split into 
greater area municipalities and provincial (town) (ilçe) municipalities. Then after İstanbul, Ankara and İzmir were formed greater area municipalities. The population of the first three big cities in 1980 were 4.7 million for Istanbul (5.8 million for the year 1985), 2.2 million for Ankara (3.3 million in 1985) and approximately 2 million for İzmir (2.3 million in 1985) respectively. As the population figures clearly reveal, the population of the third biggest cities were far above 1 million. The Municipality Ordinance No. 5216 dated $10^{\text {th }}$ of July 2004, extended the scope of the already in place Metropolitan Municipality Ordinance No. 3030, by bringing the two measurements for drawing the "boundaries" for the metropolitan cities, which are "legal administrative boundary" (mülki) boundaries and "population-radius" boundaries. According to the law, in order to determine the legal and administrative boundaries (territorial jurisdiction) for the greater area municipality limits, the domain area (etki alani), the area under the influence of the greater area municipality) defined as the magnitude of the population was taken into account. The jurisdiction of the greater area municipality has redefined them. Municipality Ordinance No. 5216, extended the metropolitan area which covers the province limits of Istanbul and Izmit. For the rest of the "biggest settlement centers", those cities which have a population under 1 million within a $20 \mathrm{~km}$ radius, those which have a population between 1-2 million within a $30 \mathrm{~km}$ radius, and those which have population over 2 million within a $50 \mathrm{~km}$ radius were drawn as the territorial jurisdiction of the greater area municipalities (Figure 1). Well known to the public as the "caliper law" (pergel yasast), the heavy political influence of the powerful metropolitan mayors for this arrangement is well known by the public [9].

With Law No. 5126 the responsibilities, authorities, and powers of the metropolitan municipalities increased, whereas duties and powers of the district and local municipality decreased. Provincial (town) municipalities (ilçe belediyesi) have lost their authority and became subordinated to the metropolitan (greater area) municipality. Some services distributed formerly by the town municipalities changed hands and became duties of the greater area municipality. The decision-making power of the district (town, ilçe) municipalities also changed and their autonomy lessened, and the power gathered at the hand of the greater area municipality. Some decisions of the district municipalities are now subject to the approval of the greater area municipality. With law, the upper level master plan's authority belongs to the greater area municipality and the lower level land use physical planning authority is in charge of the district municipality. This sharing of planning authority between these two administrative units, (the greater area municipality and the district municipality) although not worked well before, however the lessening of the district municipality planning power, does not match in any case with the authority as a local administrative unit in democracy.

\section{Implications after the abolition of the Special Provincial Administration}

In 2005, with the implementation of ordinance of Law No. 5302, the Law of Special Provincial Administration (SPA) gained its province local administrative 
body status before the "complete city law". The SPA is composed of board members selected by the local voters. The presidency of the board is selected by members of the board instead of the province governor (Vali). It is the autonomous administrative and financial public body that meets the various collective services of the province's population. Its decision board is composed of members selected by the local voters. The SPA is responsible for vast rural areas composed of many villages and provinces in the vicinity of the Greater Metropolitan Areas. The preparation of the master plans, public works, conservation of land, prevention of erosion, culture, art, tourism, social works, poverty aids, micro-credit to the poor, and various services, are amongst the responsibilities of the SPA. The autonomous administrative and financial public body exists to meet the various collective services of the province's population. In candidacy of the European Union, its local administrative status is tied to strength. Its jurisdiction was enlarged in accordance with the Public Administration Law (PAL). However this law was not enacted so the large collection of duties introduced by the PAL, from health issues to social working, education, rural services, etc., the SPA was not restructured as intended. It was established as an autonomous local administrative body; however its organizational structure and duties are nested together with the central organization. Although the construction of the SPA dated back to the end of the $19^{\text {th }}$ century in the Ottoman era, it could not reach local administration status.

\section{Abolition of the village legal entity status}

A village is the smallest and the most common local administration in the nation. Villages are subject to Law No. 442, enacted in 1924. This law has been modified twenty six times since its inception. According to this law a village is the smallest settlement unit with a population between 150 to 2000 people. Historically, villages are the oldest settlement units of mankind. The decisions made for the common needs of people stem from sharing the same living environment, accepted by the people living in that place as the basic principle of the local democracy. This is the meaning of the authority of the administrative decentralization principle. The common interests of the people living in a village are far from the shared interest of the people living in urban areas. From a legal aspect, a population living in a village which ultimately converts to an ordinary city neighborhood, will probably ask for licensing rights from the province municipality of the metropolitan administration to irrigate the land for his/her animals, thousands of kilometers away in a village. Previously with their own authority this kind of necessities would be met by themselves. However, now they have to meet their needs and services many kilometers away and be subject to decisions made by the municipal assemblies consisting of strangers to their local needs. In the village legal entity, the decision about the village settlement and their common goods and needs were made by the "village elderly board" and implemented with their own financial resources and facilities. The traditional imece system, which means the collective manpower and labor to exercise under the equal conditions to meet the village's compulsory or voluntary works of the village included in the Village Law, was practiced commonly before. It can be 
argued that the villages lack the resources and manpower to fulfill the public services, however, the abolishment of the "legal village entity" is not the solution. The solution may involve fostering their enabling capacities [10]. The abolishment of a village's legal status has major implications. The elderly village board is the public decision making mechanism and, including expropriation, the board had many executive powers. After the transformation to the neighborhood status, the village lost their executive power and opportunity to make decisions concerning their needs and they have lost control over the resources they have. A neighborhood unit now has no legal entity and power. With the regulation the muhktar (selected by the village people), the villagers had a right before the law, to apply at court on the behalf of the villagers, but now after converting to the ordinary neighborhood, the villagers cannot seek their legal rights directly in court.

\section{Planning activities in İzmir's metropolitan areas}

Negative effect of the world-wide globalization, privatization has brought substantial impact to the planning in general. After a break in centralized and integrated approaches in planning caused to redevelop and revise institutional and managerial framework of planning in the nation budget [11]. Lack of integrated positive planning approaches since 1980s is the well-known fact; however, the idea of planning can never be rejected. İmir Greater Area Municipality armored and widened in responsibility so that a new metropolitan boundary is redrawn. However, though the metropolitan boundary extended both in authority and territory, there are other central and regional public institutions responsible in planning in different scale (regional or upper-regional, or projects) and scope (one sector dominancy, tourism planning for instance). All the institutions produced plans or projects independently. All these planning activities reveal that there is plenty of planning activities, different scale, scope and jurisdiction, sometimes contradictory. There are different institutions responsible for different scales and areas. In many occasions the jurisdictions are overlapped. Planning activities are not always coordinated or co-organized properly. The common feature of all these planning efforts is mainly the "urban" focus. The intrinsic qualities and vulnerability of the rural areas cannot find a place in all these planning activities. The differences possessed by the rural areas have not been taken into account and standard, uniform construction layouts are applied everywhere.

\section{Rural areas in İzmir}

Izmir is the third largest metropolitan city of Turkish Republic. The metropolitan region is in the western part of the nation. İzmir is the second most important seaport of Turkey. The total population of the Greater İzmir Municipality is $4,005,459$ (2012). Izmir is a growing metropolitan region, having increased from a population of 2.8 million in 1990 to more than 4 million in 2012, indicating a population boom in the most recent decade. One of the important aspects of the population structure of Izmir, the share of urban population within the total 
population is considerably higher than the nation's average. Urban population in the total population has been 81 per cent whereas only 65 per cent in Turkey in 2000. In the historical perspective, the share of urban population in total was only 50.3 percent whereas rural population was 49.7 per cent. In 2012 the urban population has reached 91.4 percent and the rural percentage remained at 8.6 per cent. This is mainly the fast population growth accompanied with the changing administrative boundary. All these figures indicate that Izmir has received substantial flow of emigration from rural areas of the Aegean Region and also from other rural areas of the Nation. However, the rate of migration has in process of decreasing while in 1990 the rate of net immigration was 64 per cent, whereas it was 2.26 per cent in 2011 (IZKA, Development Agency).

When we look at the distribution of employment according to the economic sectors, 58 per cent of the active population employed in services, 32 per cent of population employed in the manufacturing whereas only 10 per cent in agriculture. The share of manufacturing has decreased from 37 to 32 per cent between 20042012, while the share of services has increased from 52 per cent to 58 per cent. The share of population in agricultural sector was trapped at 10 per cent in between 2004-2012.

Using two significant studies for the rural areas at the vicinity of the metropolitan areas, (1) TurkSTAT's "Regional Development Indicators 2008", and (2) "Izmir Institute of Technology (IzTECH) Rural Areas Settlement and Housing Inventory 2012", we summarized some important components and typology of the rural areas. In this region, there is a general tendency to migrate to the province center and center of Izmir; however the geographic location of villages, the size of arable land, and the product diversity create variations in this pattern [12]. In addition to these, the welfare level of the villages, educational level and cultural preferences of young men and women are the other factors affecting the migration. Villages have exercised high rate of migration to the urban areas in 1950s till 1970s and this trend is continuing however in a changing fashion. Today the youngsters prefer staying in their villages. At least, the tendency to stay in touch with their villages and farmland, one foot in the village or seasonally going back to the villages are common. There are families with some members emigrated to the urban areas but left behind few members in their villages. In actuality, though the difficulties of the primary sector stemmed from the shortage of arable land, limited production of new goods, land inheritance getting scarce, increasing input prices in primary sector, create tendency among youngters to migrate to the urban areas and find secure jobs for minimum subsistence. However, the urban areas are far form meeting these desires. For these reasons, the youngters, although emigrated to the urban areas, to protect their rural heritage by doing weekend labour or working as seasonal workers in summer. In addition to these tendencies, another factor worth mentioning is the decresing level of the fertility even in the villages with less migration. Nowadays, the young population living in rural areas prefer to have one or two babies. The result is the decreasing of the school age population which is accompanied by the abandonment of the school buildings. "Bussed education" has been expanding picking up students from each villages 
and carrying them to schools in the province center. Some of the students stay in boarding schools instead of being bussed to remote schools.

In the study we examine the rural areas which were under the jurisdiction of the former SPA and now they all have been converted to the neighborhood units of the town municipalities by employing an index of rurality (variables can be seen in Table 1). The planners now face with the issue of defining rurality for the rural areas in the Greater Izmir Municipality as a starting point for planning. There has been a rich literature in the statistical discourse and policy debate on the variables considered and included for the index of rurality or rural typology [13-15]. For defining rurality, a rural index is employed in order to conceptualise idiosyncratic character of the rural areas. Though all the villages under the jurisdictions of the SPA (416 villages) converted into the odinary urban neighborhood, their rural character cannot be throwed out. In accordance with Figure 2, Izmir Metropolitan area shows various level of rurality, as the villages under the jurisdiction of the former SPA, integrated rural areas, intermediary rural areas and deep rural areas. The integrated rural areas exhibit population dynamics, and although some agriculture still exists, there is increasing employment outside of agriculture. While these areas lose their traditional character, in deep rural areas, the agriculture is the main livelihood affected by the problems of aging population, lack of education and infrastructure. However, in these deep rural areas, the

Table 1: List and grading of variables used in the index of rurality.

\begin{tabular}{|c|c|c|c|c|c|}
\hline 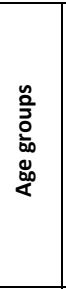 & $\begin{array}{l}\text { - Age group 0-14 } \\
\text { means young } \\
\text { population } \\
\text { - Age group } 15-64 \\
\text { economically } \\
\text { active population } \\
\text { - Age group } 65 \& \\
\text { over, aging } \\
\text { population }\end{array}$ & $\begin{array}{l}\mathrm{E} \leq 0.4 \text { (1) } \\
\text { - } \mathrm{E}>0.4 \text { (2) } \\
\text { E Elderly rate (Veyret- } \\
\text { Vernier index) = (PR> 65 } \\
\text { years) / ( } \mathrm{PR}<15 \text { years), the } \\
\text { threshold is } 0.4 \text { (A Veyret- } \\
\text { Vernier index higher than } \\
0.4 \text { demarks an aging from } \\
\text { a young population) }\end{array}$ & 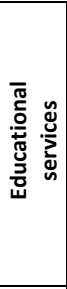 & $\begin{array}{l}\text { - Have educational } \\
\text { service } \\
\text { - Partly mobile } \\
\text { - Bussed education }\end{array}$ & $\begin{array}{l}\text { - Have educational } \\
\text { service in-situ (1) } \\
\text { - Partly mobile (2) } \\
\text { - Bussed education } \\
\text { (3) }\end{array}$ \\
\hline 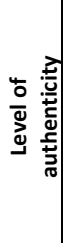 & $\begin{array}{l}\text { Evaluation depend } \\
\text { upon both } \\
\text { settlement's } \\
\text { general } \\
\text { characteristics and } \\
\text { architectural } \\
\text { characteristics of } \\
\text { the rural house }\end{array}$ & $\begin{array}{l}\text { - Non-protected (1) } \\
\text { - Partly protected (2) } \\
\text { - Highly protected (3) }\end{array}$ & 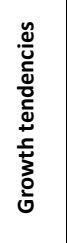 & $\begin{array}{l}\text { - Primary sector; } \\
\text { Agriculture, animal } \\
\text { husbandry \& fishing } \\
\text { - Mining } \\
\text { - Tourism (thermal+ } \\
\text { others) } \\
\text { - Manufacturing } \\
\text { - Commerce }\end{array}$ & $\begin{array}{l}\text { - Predominantly out } \\
\text { of agriculture (1) } \\
\text { - Predominantly } \\
\text { agriculture (2) } \\
\text { - Without any } \\
\text { sectoral plan (3) }\end{array}$ \\
\hline 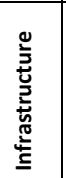 & $\begin{array}{l}\text { - Electricity } \\
\text { - Water } \\
\text { - Sewage } \\
\text { - Telephone }\end{array}$ & $\begin{array}{l}\text { - Have infrastructure (1) } \\
\text { - Not- completed (2) }\end{array}$ & 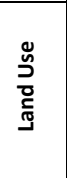 & $\begin{array}{l}\text { - Marginal } \\
\text { agriculture } \\
\text { - Agriculture } \\
\text { - Grassland } \\
\text { - Special crops }\end{array}$ & $\begin{array}{l}\text { - Marginal } \\
\text { agriculture } \\
\text { - Agriculture } \\
\text { - Grassland } \\
\text { - Special crops }\end{array}$ \\
\hline 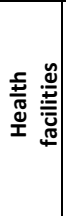 & $\begin{array}{l}\text { - Have health } \\
\text { services } \\
\text { - Not having health } \\
\text { services }\end{array}$ & $\begin{array}{l}\text { - Have health services (1) } \\
\text { - Not having health } \\
\text { services (2) }\end{array}$ & 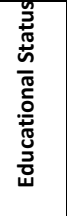 & $\begin{array}{l}\text { The level education } \\
\text { of population in } \\
\text { rural areas are } \\
\text { expected to low } \\
\text { because manual } \\
\begin{array}{l}\text { activities are } \\
\text { developed }\end{array}\end{array}$ & $\begin{array}{l}\text { - University \& over } \\
\text { (1) (\% of total } \\
\text { population } \\
\text { - High school (2) } \\
\text { - Grade school (3) } \\
\text { - Read \& write (4) } \\
\text { - Illiterate (5) }\end{array}$ \\
\hline
\end{tabular}




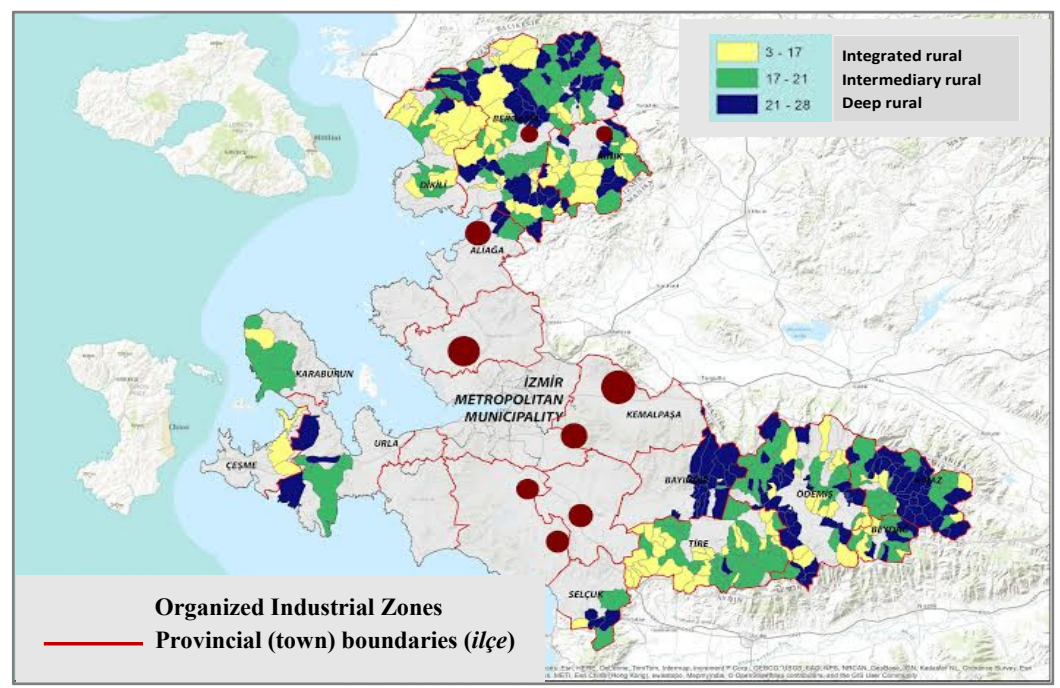

Figure 2: Index of Rurality. Source: GIS Laboratory of Izmir Institute of Technology, City \& Regional Planning Department.

villages still conserve their architectural or physical characteristics. As we can see from all these different village and rural life typologies, in Izmir metropolitan area, the human organization in rural areas, urban-rural gradient, agricultural production and non-agricultural production, the pull and push factors defined under the rubric of globalization, all these factors and their interactions create a highly differentiated and sophisticated relationship. Managing all these complicated interactions and transformation, for example regenerating the economically inactive and socially decaying areas, may be accomplished in accord with the decentralization tendencies of the urban areas and better transit opportunities, but with the unintented consquences as in the case of new construction demands which may trigger environmental risks.

\section{Conclusion}

In this study we are focusing on the reconfiguration of the 2000s when a radical transformation took place throughout the nation. Especially the rural areas around the metropolitan cities have found themselves in a different position as compared with the rest of rural areas. Per the Law No. 6360, about 412 villages at the vicinity of the metropolitan area of Izmir, were transformed into an ordinary neighborhood by removing their legal entity. This cannot be considered as a simple administrative change because the village legal entity status means that each village is a local, in-situ administrative unit established upon historical background and long traditions. The rural villages around the vicinity of the large metropolitan cities with the enactment of the law have lost substantial rights and privileges. It can be said that all these arrangements would affect agricultural 
activities negatively. Village dwellers are in danger of losing their control over their own living environment due to the competing interests such as opening up the agricultural lands to urban needs. The change in land prices after losing the "rural land" status may lead to decrease in the agricultural production and put demand on rural landscape causing abandonment and land degradation.

In Turkish Public Administration, an urban neighborhood unit is not considered as an administrative unit, and does not possess a decision board, and has no right and capacity to act (fiil ehliyeti). In contrast to the neighborhood, a village can take legal action, or file legal issues with the court, become defendant or plaintiff. The only option for the former villages is to file their problems with the province municipality within their jurisdiction [10]. The decentralization of the administration and local democracy mean that the decisions can be taken collectively by the local people and they have the right to protect their rights. For decades, this right has been provided by giving the legal entity status. All the niches of the public administration have been woven together by regulating the rights of the villages as a legal entity. Without a legal entity it is hard to say neither local democracy nor the bottom-up local administration exists. With the abolishment of the mukhtar and elderly board, the village residents have lost their right for justice [10].

All these arrangements and changes in the administrative structure and legislation have caused highly differentiated and complicated metropolitan city composition. With the winds of the globalization, the transformation of the large industrial cities; İstanbul, partly Ankara and İzmir, to the city-region is a reality. They reveal rather sparsely and far more extended morphologies and they all have difficulty to sustain their efficiency. All these series of regulations and legislations can be evaluated as attempts to manage the changes; however, they probably lead to some adverse implications. It is now much harder to manage and plan the developments in surrounding places with vulnerable ecosystems. As the locales and villages have lost their control over their own resources and more and more they find it difficult to raise their voices politically and legally. The excessive empowerment of the central metropolitan municipality on the vast metropolitan area may also cause more fragmented, compulsory, and ad hoc intervention without taking the locals demands and aspirations into account. The lack of democratic representation and local democracy create apathy towards future planning [9]. With the enactment of the new Laws and regulations the local authority's tasks and responsibilities have been extended beyond their boundaries including rural areas at the vicinity of their regions. This would bring the need to improve local institutional capacity. With the existing situation, local authorities struggle technical, administrative and financial bottlenecks. Governance and local participation of the central decision making is weak and precarious in Turkish context in general. On the other hand, even though the metropolitan boundary extended both in authority and territory, there are other central and regional public institutions responsible in planning in different scale (regional or upper-regional, or projects) and scope (one sector dominancy, tourism planning for instance). All the institutions produce plans or projects independently. However, despite all these 
negative implications of the new Laws and regulations, local authority's task for planning can be conducted in a more integrated and holistic ways.

All these transformation and radical changes offer planners with new challenges and force them to re-consider their traditional roles. The newly emergent administration pattern from rural to urban scope and new urban growth exercised by the winds of globalization has not found a place in the modern planning. Old dichotomies rural/urban, industrial/agricultural, city/village has been used in previous planning; however, it is not possible in the new era to employ old dichotomies. The focus of the explanation of the deviation between expected and observed situation has always been heavily the "urban". As planners, we need new forms of explanation to comprehend the decrease in the pull factor of the urban areas and on the other, introduce new instruments and alternative ways to increase to increase the control of the occupants of the rural areas over their lives.

\section{References}

[1] Kıray, M. (1999) Modernleşmenin Temel Süreçleri (Basic Processes of the Modernization), in Z. Rona (ed.) International Conference on "History of the Turkish Republic: A Reassessment" (proceeding), Bilanço 1923-98: Türkiye Cumhuriyeti'nin 75 Yllına Toplu Bakış" Uluslararası Kongresi, Volume II: Economy, Society, Environment, 10-12 December 1998 METU, Ankara, Turkey, Tarih Vakfı Yayını, İstanbul 1999.

[2] Buğra, A. (1998) The Immoral Economy of Housing in Turkey, International Journal of Urban and Regional Research, 1998, 22 (2): 283302.

[3] Miraftab, F., Revisiting Informal-Sector Home Ownership: the Relevance of Household Composition for Housing Options of the Poor, International Journal of Urban and Regional Research, 1997, 21: 303-322.

[4] Roy, A. \& Alsayyad, N., Prologue/Dialogue: Urban Informality: Crossing Borders, in A. Roy and N. AlSayyad, eds., Urban Informality: Transnational Perspectives from the Middle East, Latin America and South Asia, Lexington Books, 2004.

[5] Keyder, Ç., Globalization and Social Exclusion in Istanbul, International Journal of Urban and Regional Research, v: 29/1, March 2005; 124-134.

[6] İzci, F. \& Turan, M., Türkiye'de Büyükşehir Belediyesi Sistemi ve 6360 Sayılı Yasa İle Büyükşehir Belediyesi Sisteminde Meydana Gelen Değişimler: Van Örneği (Metropolitan Municipality System in Turkey and Changes Taken Place in Metropolitan Municipality System with the Law No: 6360: Van Case), $S D$ University, The Journal of Faculty of Economics and Administrative Sciences, 2013, 18 (1): 117-152.

[7] Tekel, A., Türkiye'de Metropoliten Alan Yönetiminden Metropoliten Yönetişime Geçiş: Ankara Örneğinde Bir Değerlendirme (Transition from Metropolitan Area Management to the Metropolitan Governance: An Evaluation based on the case of Ankara). SÜ İIBF Sosyal ve Ekonomik 
Araştırmalar Dergisi (Journal of Social and Economic Searches), 2009, 12 (18): 191-214.

[8] Güler, B. A. Türkiye'nin Yönetimi-Yapı (Turkish AdministrationStructure), İmge Kitabevi, Ankara- 2010: 237-246.

[9] Şahin, Z., Türk Kamu Yönetiminde Mekan ve Ölçek Sorununa Büyükşehirlerden Bir Örnek: İlçe Belediyelerinin İmar Planlama Yetkileri, (Problems of Space and Scale in the Turkish Public Administration by looking at an example from the Greater Area Municipality: Land Use Planning Jurisdiction of the Provincial Municipalities, TEPAV Foundation of the Turkish Political Economics Search www.tepav.org.tr., (13.04.2012).

[10] Gözler, K. 6360 Sayılı Kanun Hakkında Elestiriler (Critiques about the Law No. 6360) Legal Hukuk Dergisi, February 2013, 11 (122): 37-82 www.idare.gen.tr/6360-elestiriler.pdf.

[11] Oral, Y. M., A Brief History of Urban Planning Events in "İzmir/Turkey", in Göksu, E., Dündar, Ş., eds., Urban Historical Stratum: From Smyrna to Izmir, DE ̈̈, Faculty of Architecture Publication, İzmir, Neşa Ofset, (2010).

[12] Izmir Institute of Technology (IzTECH), Rural Areas Settlement \& Housing Inventory, a Research conducted by the İzmir SPA, 2012.

[13] Dalal-Clayton, B., Dent, D., \& Dubois, O., Rural Planning in Developing Countries: Supporting Natural Resource Management \& Sustainable Livelihoods, 2003, Earthscan.

[14] Frutos, L. M., Human Organization in Rural Areas, in F.B. Golley \& J., eds, Rural Planning from an Environmental System Perspective, 1999, SpringerVerlag New York, Inc., 195-217.

[15] Gülümser, A. A., Baycan Levent, T., Nijkamp, P., Turkey’s Rurality: A comparative analysis at the EU level, $46^{\text {th }}$ Congress of the European Regional Science Association Enlargement, Southern Europe and the Mediterranean 30 August-3 September 2006, Volos, Greece.

[16] IZKA, İzmir Development Agency Regional Plan, 2014-2023.

[17] TurkSTAT, Census of the Population of the State Institute of Statistics, 2012.

[18] TurkSTAT, Regional Development Indicators 2008. 